\title{
Protectionism: This Good Bad Word
}

\author{
Gabriel Anibal Monzon \\ Degree in Economics, Public Accountant \\ Degree in Administration, Magister in Business Administration (U.C.L.A), \\ Magister in Administration and Finance (UNAM) \\ Dr. in Economics, Technical Secretary of the Parliamentary Confederation of \\ the Americas, University of Flores, Argentina
}

Doi: 10.19044/esj.2017.c1p8 URL:http://dx.doi.org/10.19044/esj.2017.c1p8

\begin{abstract}
This paper aims to determine the place the economy occupies in sciences and, in turn, the place occupied by Protectionism like school of thought within the economy. From the origin of the stipulated capriciously of the economy as Normative Science, the concentrated economic power has tried in creating awareness among people that Protectionism is harmful. As a result, the only way to development and welfare is Liberalism. This position, convenient for those who are directly benefiting from the accumulation and concentration of wealth, involves the one they have been promoting from the media. It is assumed as an absolute truth and is used for generating the collective consciousness that Liberalism is the only way out. In addition, this is even at the expense of the interests of the people.
\end{abstract}

Keywords: Economy, protectionism, liberalism, development, people

\section{Introduction}

Is Protectionism a tool for commerce or is it a philosophical current inside the economy? Is it only an invention created to justify the mercantilism and today's anachronistic? Is it only an economic school that brings decadence? Is liberalism the only economic current that allows development? Why does liberalism has better press than protectionism?

Many of these questions have actionated in the unconscious group to position protectionism like something bad. Hence, this is contrary to nature, and it leads to poverty and to the enrichment few people.

Protectionism is part of the culture of people. From economic power, impeller of Liberalism, they have sought to generate an awareness that Protectionism is contrary to the development of peoples and nations. This hides the historical reality that that is what allowed the origin of the rational 
exchange between different tribes, cultures, civilizations, nations, and peoples throughout history.

The communication strategy highlighting the virtues of Liberalism as the only way to development was contradicted by culture and effective reality. This was embodied in concrete data from the positive economy.

In this study, I will develop the hypothesis that the injury of Protectionism is only useful for economic power to establish the idea that Liberalism is the only way to development.

In this essay, I will kick start to begin to understand why protectionism is considered as a "bad word", being a school that generates welfare people.

\section{I.}

\section{Origin of Protectionism}

The controversy about the origin of economic Protectionism has been generalized since the emergence of the international trading system. Subsequently, this is with the advent of the concept of country. Also, it is closely linked to Mercantilism. The irruption of the Physiocrats, by the hand of Quesnay as main reference, was provoking the general and erroneous idea that the natural thing is the Liberalism. Nevertheless, there is a force with which Liberalism is imposed on collective imagination, even against the interests of the majorities. It is long-standing and responds to a very intelligent way of advancing the community. This can be achieved by making each of the soldiers to become members of the free trade and Liberalism, even at the expense of their own interests.

From the origin of the tribal economies, there existed a concept of necessity and opportunity. Inside the tribe, the needs were solved in solidarity. It was often ordered by someone who is responsible and others by the collective. When the absence of any element could be provided by another tribe, an exchange (barter) system based on protectionism was generated. As a result, the tribes sought what they lacked and toasted to what was left over. That way, no one could think of putting aside what he needed to deliver for something that he did not. When any "stranger" wished to appropriate something that is necessary for him and which is not surplus on the other side, disputes tends to arise. Therefore, this has not changed beyond the years and forms.

Adam Smith (1794), father of economic liberalism, recognizes that for barter to be possible, there must be a surplus to be changed. In this way, Smith begins to justify his theory about the division of labor.

Anyone who, in the matter of his interest, stipulates another, intends to do this: "Give me what I need, and I will give you what you lack." This is the intelligence of such compromises, and this is the way to obtain from another 
greater part in the good offices that it needs in the commerce of the civil society. (Adam Smith, 1794)

It remains clear from that time that the author, also considered father of the economy like science, recognizes that Protectionism is previous even to the formalization of the Economic Science. Therefore, it is the natural behavior of men.

The concept of the man I use in this essay, as opposed to the individual man determined from the liberalism that must be used to justify his theories, is that of Social Man. Man is a social being because that is the only way he can develop. Already, Aristotle (330 BC) in Politics states that "Man is a social being by nature". It is in this sense that man "is" in both "is with anothers".

In the beginning and in returning to the barter model described above, it was much easier to exchange necessary goods because there was no money. This, however, refers to the intermediate good par excellence. Consequently, we must clarify the fact that barter was not an extended practice. It was done between different people and as a result of the surplus of what was needed and the needs of the needy.

As we advance in the evolution of humanity, we can appreciate the advent of commerce. From its origin, commerce between cities was given on the basis of the concept of missing need. In the absence of some goods, it was accepted by others that offered it. On the supply side, they offered what was left over. Therefore, there is the need to grow articles that were not necessary for subsistence. Also, Protectionism is closely linked to subsistence.

It was described above that man-made economy, from its origin, begins to manage its resources to meet their needs as soon as possible. This is based on the concept of the collective, the supply, and the management of the resources of the clans and tribes which generated the concept of distribution and savings.

After this, and with the connection with other clans and tribes, the concept of the exchange arose. No group was going to give up what it needed. Thus, it was done through two ways: the submission by force or the exchange for things that is needed and which they do not have. It also entails yielding what they had and did not need.

This remnant concept began the idea of commerce: the production of goods that were abundant knowing that for other groups it was not. It also obtained what was needed through barter.

Thus, what has always given me concern is the widespread consensus of the birth of the Economy in the Modern Age, and coincidentally with the advent of Economic Liberalism. Moreover, after what I am expressing till now in this work, this has added two justifications to my criterion:

- $\quad$ The first is that with the first writing of economic philosophy, the economy is born as a science. 
- $\quad$ The second is that it is convenient to establish the birth and imposition of the economy as a science when a theory is expressed whereby the individual (liberalism) is justified and prevails over the collective (protectionism). As a result, he establishes as natural the inequality from those sectors that need to disguise that difference to continue exercising the power.

\section{The Economy and its Place in Science}

In making a historical journey, Economy (whose literal translation in the Greek is The Law of the House) like discipline goes back to the origin of humanity. However, the first that was characterized were the Greeks. The old economy was based on administration and not on profound study. In the middle ages, feudalism and scholasticism also made their contribution. The advent of modern economics can be synthesized into Mercantilism and Physiocracy.

We deduce that Protectionism emerges in advance of Economics as a science. This means that after the practice of economic activity, the scientific theory was generated. Consequently, we are faced with the first paradox. While Economics as a science is attributed to Adam Smith, with the generation of norms and laws that govern it, the reality is that Positive Economics is much earlier than Normative Economics. Therefore, this moment determines its entrance to the world of Science.

In extending this, I am going to quote some authors.

Mario Bunge (1959) in "Science: His method and His philosophy", divides science into two great branches: Formal and Factual. Broadly speaking, I can say that Bunge states that the formal sciences speak of ideas and factual facts.

However, Economics, as most of the social sciences, is based on formal studies of factual activities. Taking an example from the postulates of the formal sciences, we can determine that in the face of the increase in the prices of goods, its demand falls. This is based on a shortcut called "Ceteris Paribus" which means that we modify a single variable and assume that all others are fixed. In this case, we assume that the only variable that moves is price. Now if we transpose this to facts, we can never keep all variables constant. Therefore, we are trying to generate ideal norms to apply to real contexts.

Furthermore, this brings some problems of interpretation and, on the other hand, the possibility to manipulate the readings of realities from the ideal postulates. It also establishes great zones of conflict.

In return, can we think then that Economics escapes the drastic division of science established by Bunge? This hypothesis is not crazy.

Meanwhile, Paul Feyerabend (1975) defines the traditional definition of science and states: 
The difference between epistemological theory (political, theological) and scientific practice (political, religious) that emerges from these quotations is usually formulated as a difference between rules or standards "certain and infallible" (or in any case clear, systematic, and objective) and "our fallible and uncertain faculties which depart from them and fall into the error". (Feyerabend, 1975)

The author determines that anarchy is what really makes progress to science, challenges the previous postulates, criticize them, allows new methods which is not regulated to arise, and favors the revolution by modifying a part or the whole.

According to Feyerabend, I understand that I must make that venture to economic science. Thus, the only way to obtain observations and factual development is escaping from norms or creating new norms. In this case, we can identify what criterion is Economy as a science. "Stable facts arise and are maintained despite the vicissitudes of history." They are forced. They generate their own ideals and reality. Also, complete and complex observation is unknown. At this point, this is regarded as the problem.

Having determined that man is a collective being, and that by definition Economics is a Social Science, can we then base all economic scientific theory on man as an individual being, and not as the subject that must be for a social science? Definitely not.

\section{Protectionism and its Place in Economic Science}

It is normal to ascertain the milestone for the recognition of a science for the first formal treaty. What is not normal is that the first treaty which is considered foundational will be written. This is done after the same science recognizes that, prior to its release, there already exist schools that are the same. In this case, economic science was recognized prior to its release to Mercantilism, especially because Mercantilism also generated laws of science. One of these was based on Protectionism as international trade policy. This however is with the objective of obtaining precious metals through the exchange.

There is another point that is much more complex. The generation of awareness in the popular sectors which shows that Liberalism is the only thing that allows development was justified in the concept of the invisible hand. This was stipulated by Adam Smith: "if each one is fine, we all are fine."

The general welfare comes if everyone seeks their particular welfare. However, this concept where we are all "free and equal" to the economy has a vice of origin because there are really different levels of access to opportunities and power. This is because I can determine that the generation of the consciousness of something is natural when in reality is unnatural. Thus, this is only to justify the action of the most powerful economically. 

word?

Now then, Why do they try to establish that Protectionism is a bad

Liberal school is based on the individual concept. It is the most widespread from an academic point of view due to the laws of accepted science generated from it and with the limitation of the already mentioned concept "Ceteris Paribus". From there, everything that propose a collective action of development has no place. This is why the adherents to this current of economic thought stated that it is necessary that there should be nonintervention of the State. Also, the invisible hand established by Adam Smith in his Theory of Moral Thinking should be well maintained.

From that same school, it is said that any protectionist measure is unnatural (contrary to the origin of protectionism), and will only have harmful effects. As a result, they try to explain that protectionism involves tax increase, loss of jobs, price increase, debt crisis, and transfer of income in the hands of a few.

But is this true? First of all, I analyzed the liberal economy.

In the course of free trade, which theoretically determines the perfect competition market, you must comply with certain circumstances. These include:

- Infinite buyers and sellers.

- $\quad$ All are on equal terms: buyers with the intention and ability to acquire and sellers with the intention and ability to offer.

- There are no barriers to enter or exit.

- $\quad$ All buyers and sellers handle the same information.

- $\quad$ Sellers are aiming to maximize their profit (selling as expensive as possible) and consumers to satisfy their need with the lowest possible price (buy as cheaply as possible).

- $\quad$ All goods are the same regardless of the supplier from which they were gotten.

If I analyzed one by one, with the exception of the third rule and only because is factually possible, none can be translated into a concrete reality. From this, in Economics, the whole theory is simply a frame to establish norms (hence the concept of Normative Economy) of a science which when managed in this way is impracticable.

In fact, all solutions to concrete problems from this theoretical framework failed. There is no scope where purely classical theory can be applied. Thus, this is not to lower the value of Science, but to put in value for the positive concept of Science.

The controversy that I seek to elucidate at this moment is the place that occupies protectionism within the economic science. Therefore, this is previous to the formalization of this one. 
The concrete reality is that from a school of economic thought (Liberalism) constructed in an ideal framework, it denies another previous school and emerged from the concrete observation (Protectionism). This has as an explanation on the inconvenience of demonstrating the virtues of Protectionism by the liberal economic order constituted as a factor of power.

\section{Protectionism Enemy of the Liberal Economic Power}

From the beginning of civilization, the inequality between men was constant. The societies were built with hierarchical structures. Historically, they were two: one of religious order, and the other of political order. Then with the concept of wealth, a third order arises: the economic one. This put a new player in the bidding of power. A power that was already consolidated and divided in a practical way and that for centuries carried a co-existence with ups and downs. Nevertheless, coexistence at last did not clearly see the appearance of this new player. Even in modern times, in some cases, it is not entirely clear.

Throughout history, these three orders were congruent. What must have been normal (going through separate lanes) was transformed into the exception to rule. Economic power began to be a determining factor in the decisions of the other established orders. From that place, with the ambition as north, the economic order is camouflaged in the other two which aims to be the Superior without being noticed openly.

Examples of this exist in the past and present. Then I ask myself: if the economic order as an instance of power is generated by those who concentrate income and make others play their games. Is it illogical to think that Liberalism should be exalted and protectionism reviled? Protectionism as an expression of collective interest is an enemy of those who consolidate economic power.

The political order in mercantilism, before the advent of liberal thinkers, promoted this school from the political structure (the ancient kingdoms show that the most powerful country has more precious metals especially since the discovery of America's large reserves of gold and silver). Here, wealth and political power had the same formal heads.

That is why the State was regulating the actions of the economy and was encouranging the imposition of economic barriers to the products that could be imported. In turn, it was encouranging the exportation of everything as a means of accumulating wealth. This was the Power.

Let's not be naive. Since the economic power and political power are the same, everything was mostly water for the same actors. The most powerful State was the one that had the most wealth of precious metals. Therefore, the most powerful King was the one that reined over that State. 
With the advent of the physiocracy and the depletion of the mercantilist system, thanks to the start of the process of independence of the countries of America, there was a division between the kingdoms who held up mercantilism. This generated a contest which resulted in the concept that the State is the enemy of economic efficiency.

The Industrial Revolution changed the structure of economic power by only changing the actors. Although the regime was feudal formerly, the owner of capital in the new industrial scheme is consolidated as a member of the supremacy within the economic order. I differentiated economic power from economic order and it is of significant importance that this is done.

The articulation of the economic power with the political power was swinging throughout times. In Mercantilism, political power conditioned economic power, basically because $90 \%$ was the same. Abolishing the concept of mercantilism with the concept of Physiocracy, on the one hand, and the emergence of Economic Liberalism, on the other, imposes the individual on the collective. This is because the owners of economic power are strengthened and need this concept to still remain more powerful.

The political power is subjugated by the economic power. It is necessary, in order to convince the people, that the individual order should be established as a natural order. Meanwhile, religious power remains observant. It is being used by the other two powers. In this context, the protectionism which is considered as a commercial policy of Mercantilism should be discarded.

In 1891, Pope Leo XIII begins to weigh the religious order through the Encyclical Rerum Novarum. Here, far from being extinguished, he denounces and opposes economic liberalism and the exploitation of man by man who takes aberrant characteristics to form the Industrial Revolution.

Also, 40 years later, the Pope Pio XI issued the Encyclical Quadragesimo Anno in the same direction, extolling the Social Doctrine of the Church and the concept of Social Justice.

In this, returning to expose the virtues of the Rerum Novarum, it was manifested:

\section{Occasion}

3.So, at the end of the XIXth century, the exposition of a new economics sistema and the development of the industry had come in most of the nations to the point that saw the human society more and more Split into two clases: one, certanily slighty numerous, that enjoyed almost the totality of the godos that so copiously were providing the modern inventions, while the other one integrated by the enormous multitude of the workpeople, oppressed by distressing misery, fought to be liberated in vain of the oppresion in which they were living. (Pope Pius XI, 1921) 
The denunciation of the reality about the concentration of the wealth begins to draw a glimpse of a strong criticism to the liberalism that is manifested later when it says textually:

27. The encyclical Rerum Novarum, effectively, by vacillating the principles of liberalism, which for a long time had been impeding an effective work of the rulers, impelled the Peoples same to foment more truly and intensely a social policy ...

The religious order weighs down its power and manifests itself strongly marking the inequality that Liberalism brings and condemning that it is unnatural. Also, it goes further to dictate that "To free competition make happen the economic dictatorship."

I can affirm then that Protectionism is an economic school that is intimately linked to the collective. It considers man as a social being and one who understands that inequality is aberrant in as much as it allows the exploitation of man by man. This is the enemy to be defeated by the economic power that determines Liberalism. In addition, it must be away from the popular sectors to which it benefits and generates the awareness that it is bad and contrary to the interests.

\section{Reflecting on the introductory questions}

Protectionism: Is it a tool for the commerce or is it a philosophical current inside the Economy?

According to the Spanish Royal Academy, protectionism is "an economic policy that hinders the entry into a country of foreign products that compete with nationals."

My definition of Protectionism is as follows:

"School of economic thought that protects the industry of a country and with it its sources of employment, industrial matrix, distribution of income and stimuli to investment through policies that allows to generate advantageous competitive conditions of national versus foreign, emphasizing the welfare of the Peoples."

Analyzing my definition, I can say that it is a school of economic thought because this adheres to a philosophical current which encompasses much more than the economic fact. It is not limited only to the trade. Its scope is broader and involves a philosophy where the economy is part of a whole and not an isolated fact. Also, it includes monetary policies to stimulate investment and the distribution of income, industry promotion, job creation and a fair local tax structure and the well-being and development of peoples in the North. It is closely linked to the concept of Sovereignty, and that is the main object of attack from liberals and classical schools.

This can approach the Factual Science of Science, although it contains important components of formal science according to the division of Mario 
Bunge. In turn, it is identifiable with the anarchic method proposed by Feyerabend from the scientific point of view. The contingencies or stimuli is not always the same and are often, in many cases, novel.

Protectionism was and is a scientific manifestation of the collective. Within its field of study, in addition to the concept of Nation, the concept of well-being of the peoples is pre-eminent. It emphasizes the distribution of income for the generation of a virtuous circle which starts with consumption and energizes the entire economic circuit.

Is Protectionism only an invention created to justify the Mercantilism and today anachronistic?

Protectionism in its origin was a policy within the mercantilism. Stronger countries are those who have a greater quantity and quality of reserves. This is not far from the mercantilist concept of power. It would be worthwhile to think if the power structure of the current nations is living a Neomercantilist Era. The accumulation of wealth and the planning for the sustainability of the environment are current components for the measurement of economic power.

Protectionism is a comprehensive school. It not only covers national enrichment and the sustainability of resources, but it has its main objectives of the decline of the Gini Index. Gini index is expressed in percentage terms. Gini coefficient is used to measure inequality in incomes within a country. The Gini coefficient is a number between 0 and 1 , where 0 is perfect equality and 1 the maximum inequality. Therefore, it is imperative to understand that protectionism not only pursues the economic development of a nation, but also pursues the generation of employment and the distribution of income and development. Not only does it think of the nations, but it makes the people a macroeconomic object.

Therefore, far from being anachronistic, it has full force and is a necessary school to equalize inequalities.

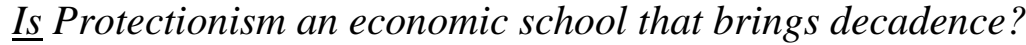

According to what I said in one of my works, published in the European Scientific Journal (Monzón Gabriel Anibal, 2017), I established that protectionism, far from generating decadence, leads to the development of the people. I also stated that protectionism is the creator of employment. It affects the reduction of tax pressure and determines an increase in real income. As a result, the wage-price ratio becomes more beneficial for the population. In addition, the accumulation of reserves allows the solving of the debt crisis.

All these points are those who criticize protectionism from liberalism as a business tool. Nevertheless, as I have already stated, protectionism is a 
school and a current of thought that transcended to mercantilism. Also, it is inserted in the philosophical current serves as Social Justice.

While those who adhere to the Liberal school argue that the consequences of protectionist policies with respect to international trade are dire, they have never developed in their line of thought the fundamental and transcendent fact that protectionism is a much greater current of thought than Commerce. However, commerce is a school within the economy as a science. This adheres to the realities of the factual sciences and to the strength of Positive Science whose objective involves the analysis of the facts and the possibility of generating advances that can be expressed in realities.

\section{Is Liberalism the only economic current that allows development?}

For a long time, economic power set up the idea that the only economic school that enables the development is liberalism. By what I have written here, I can prove that it is not so. I will give an example.

In Argentina, from the 1990s to the beginning of 2003, the applied economic policy was the one recommended by the multilateral credit agencies with a strong liberal accent. The International Monetary Fund recommended the implementation of policies that encouraged the nonintervention of the State. This is with a reduction of the same and the liberalization of the borders which allows free trade.

The most important indicators of Argentina were the external debt with respect to the Gross Domestic Product and the Gini coefficient or index. These two indicators will allow us to appreciate the effect of liberal policies on the one hand and protectionist policies on the other hand.

The Gini coefficient of Argentina of 1990 was 0,439. After the period of liberal policies in 2002, it had risen to 0.53 . Income inequality had increased by $20.45 \%$.

On the other hand, the external debt was $40 \%$ in relation to the Gross Domestic Product. After the liberal stage in 2002, the external debt was $145.9 \%$ of GDP.

Liberal policies deepened social inequality, generating a significant concentration of wealth that benefitted the referents of the economic order. This led to a decrease in the quality of life of the popular sectors (workers, pensioners, unemployed). On the other hand, it resulted to the brutal debt that did not result in works that generate employment and income. This resulted in the default of Argentina.

Something similar has been happening since 2016. Argentina borrowed from December 2015 to September 2017 at the rate of 200 million dollars per day. We have an absolute increase of almost 100 thousand million dollars. The Gini index, for its part, had an increase of $7.3 \%$ from December 2015 to December 2016. 
These numbers was revealed in a particular case with data from the World Bank and ECLACL. ECLAC is an agency of the United Nations. Its symbol represents the Economic Commission for Latin America and the Caribbean. It shows that liberal policies is away from generating and it allows development to bridge the economy, concentrated incomes, and increased social inequality by avoiding the proliferation of developmental foci.

On the other hand, and by always dealing with the statistical data, I can determine that during the protectionist period (2003/2015), Argentina reduced the ratio of external debt to the Gross Domestic Product from $145.9 \%$ to $53.5 \%$. Meanwhile, the Gini coefficient was 0.41 at the end of 2015. It grows again since that time at the end of 2016 to 0.44 .

Liberalism, then, tends to increase inequality and concentrated income in most economically powerful sectors.

\section{Why Liberalism has Better Press than Protectionism?}

According to what we live, every time in the media, we stated that protectionism is automatically associated with something bad, pernicious, and harmful to people and nations. Meanwhile, liberalism enjoys a better press, and is being used as a policy linked to development and that generates welfare.

At this point, I must return to what I have already raised in this essay: the existence of at least two active powers which are political power and economic power. From the latter which is exercised by a few and without any legitimate representation more than the wealth accumulated by them, there is an important pressure in the media to ratify the idea that liberalism is a good word, while protectionism is not.

Liberalism needs to be sustained in order to maintain the prevailing statu quo, in order to generate a collective awareness that it is good even though the popular sectors are worse. This is with the important mission of generating more needs to turn people into slaves of consumption. Consumption, in a liberal doctrine, enriches a few who are the owners of economic power.

Furthermore, you must not wonder that the media support this way to generate opinion, since the mission of the media is not in reporting. Basically, the media are companies, and all companies are looking for profits. This is simply because they are part of the economic power. If I analyze in all parts of the planet the corporate formation of the mass media, I can surely state that they are composed of important members of economic power.

In this context, it is essential to maintain that protectionism is considered to be a harmful doctrine that violates the freedom and power that go against development. Since it is linked to the concept of sovereignty, protectionism automatically becomes something to defeat. Also, this is 
attributed to the fact that the economic capital has no borders. The economic development needs state intervention and state protection.

\section{Conclusion}

In conclusion, I reflected on the following sentence of John Maynard Keynes:

The individualism of political philosophers points to laissez faire. The divine or scientific harmony (as the case may be) between private interest and the public interest points to laissez faire. But, above all, the ineptitude of the public administrators inclines decisively to the practical man in favor of laissez faire, a feeling that has by no means disappeared. Almost everything the State did in the XVIIIth century, above its minimum functions, was, or seemed, detrimental or unfortunate. (Keynes John Maynard, 1926)

This economist, who endorses the intervention of the State to regulate the economy, explains to us that liberalism is an individual construction. Although he justifies selfishness in the inefficiency of the public administration, he leaves open the debate about the end by stating that what the State did above its minimum functions was or seemed detrimental or unfortunate. In this sense, it is where protectionism and liberalism from the political philosophy collide because the "minimal functions" raised by Keynes are different.

Keynes reveals his liberal roots in this paragraph. The State, according to the doctrine it represents, has different priorities. In economics, the role of the state in liberalism is nonexistent, while protectionism is active and intense.

In short, the centuries have passed and the controversy over power is the same: political power vs. economic power.

Economic power has in its ranks the media as its most effective tool to generate, in the collective unconscious, the ideas that suit their interests. It is imperative for economic power to generate the false consciousness that Protectionism is harmful and detrimental to the people.

They must create the false conviction that Protectionism is a "bad word" when in fact it is an economic current that leads to the development and progress of the people.

\section{References:}

1. Smith Adam (1794). Investigación de la naturaleza y causa de la riqueza de las naciones. Capítulo II. Tomo 1. Oficina de Viuda e Hijos de Santander.

2. Bunge Mario (1959). "La ciencia. Su método y su filosofía”. Grupo Editorial Argentina. Introducción. Pág. 6.

3. Feyerabend Paul (1975). "Contra el Método. Esquema de una epistemología anarquista” NLB Londres. Prefacio. Pág. 2. 
4. Keynes John Maynard (1926) "El final de laizzes faire (Ensayos de Persuasión). Editorial Síntesis. 2009. Pág. 277.

5. Monzon Gabriel Aníbal (2017). ). Protectionism or Free Trade? Dilemma of Regional Integration an the difference between Peoples or Countries. A critique to Miller \& Elwood. European Scientific Journal. Special Edition. June 2017. Recovered from www.eujornal.org

6. León XIII Papa (1891). Encíclica Rerum Novarum. Editorial Vaticana. 7. Pío XI Papa (1921). Encíclica Quadragesimo Anno. Editorial Vaticana. 